\title{
Implementasi Gugatan Legal Standing dan Class Action dalam Praktik Peradilan di Indonesia
}

\author{
Bambang Sutiyoso
}

\begin{abstract}
The implementation of group representative accusation especially for legal standing in the practice of judge in Indonesia is still faced with the handicaps procedural technically. The regulation of legislation is still restricted in law material, while in formal law (the court of justice) is not regulated clearly. The uncertain of procedure in formal law (the court of justice) in its regulation is really not the handicaps for the judge for taking the just decision, because the judge can apply the other law resource. Although, it has been issued PERMA No. 1 the year 2002 that regulate the group representative accusation, for the next it should be formulated strictly in the new Justice Court of Code Procedures. The group representative accusation is the more simple justice altemative, quick and low cost.
\end{abstract}

\section{Pendahuluan}

Putusan PN Jakarta Pusat yang menerima dan mengabulkan gugatan AJl terhadap Kapoli c.s. beberapa waktu yang lalu, merupakan momentum yang baik bagi dunia hukum dan peradilan. Vonnis putusan PN Jakarta Pusat tersebut tentunya melegakan banyak pihak dan seolah-olah sebagai "air penyejuk" bagi kalangan pencari keadilan, insan pers dan masyarakat pada umumnya, mengingat selama ini ada kesan untuk mendapatkan keadilan di pengadilan sangat sulit, berliku-liku, bahkan sering berakhir dengan kekecewaan. Dengan vonnis putusan tersebut, berarti lembaga peradilan sudah memberikan "green light" terhadap eksistensi gugatan legal standing di Indonesia dan sekaligus sebagai perkembangan bagi dunia hukum yang menggembirakan. Putusan yang langka tersebut secara tidak langsung semakin memantapkan eksistensi gugatan perwakilan kelompok, khususnya legal standing di Indonesia.

Munculnya beberapa kasus gugatan perwakilan kelompok, khususnya legal standing ke pengadilan merupakan salah satu fenomena baru dalam praktik peradilan perdata di Indonesia. Meskipun demikian, pada umumnya gugatan legal standing yang diajukan ke pengadilan selama ini hampir selalu dinyatakan tidak diterima atau N.O. (Niet. Onvankellijk verklaard). Hal itu terjadi karena berbagai alasan tentunya. Di antaranya adalah secara prosedural gugatan' legal standing 
belum diatur secara jelas dalam perundangundangan (hukum acara perdata). Di samping itu sering pula dipersoalkan apakah pihak penggugat yang mengajukan gugatan secara hukum mempunyai kapasitas atau. kewenangan untuk mengatasnamakan kepentingan publik atau kelompok masyarakat yang diwakilinya. Di samping itu, menurut hasil penelitian Sundari' karena belum begitu dikenalnya atau dipahaminya prosedur tersebut secara luas baik oleh para pencari keadilan, para pengacara/advokat, maupun hakimnya sendiri. Hal tersebut juga nampak dari domisili para penggugat yang sudah menggunakan prosedur gugatan semacam itu pada umumnya terbatas di Daerah Khusus Ibukota Jakarta.

Dalam konteks itulah, tulisan ini berupaya menyoroti beberapa aspek permasalahan yang sering muncul berkaitan dengan embaga hukum legal standing di Indonesia, implementasinya dalam praktik peradilan, halhal yang dipersyaratkan dalam gugatan perdata konvensional, serta kemungkinan langkah terobosan hukum oleh hakim dalam upaya mengantisipasinya. .

\section{Legal Standing dan Class Action}

Membicarakan gugatan legal standing pada umumnya selalu dikaitkan dengan gugatan class action, karena baik gugatan legal standing maupun class action, pada hakekatnya merupakan bentuk gugatan perwakilan kelompok, yaitu gugatan yang mewakili kepentingan publik atau kelompok tertentu dalam masyarakat. Gugatan perwakilan-kelompok ini pada umumnya diajukan oleh kalangan masyarakat maupun Organisasi non Pemerintah (ORNOP) yang bertindak mewakili kepentingan publik atau kelompok masyarakat tertentu dalam upaya untuk memperjuangkan hak-hak dan kepentingan mereka yang dirugikan. Kelompok masyarakat yang berkepentingan ini biasanya terdiri dari banyak orang, yang jumlahnya dapat mencapai puluhan, ratusan, ribuan atau bahkan jutaan, sehingga sangatlah tidak efisien. manakala kelompok masyarakat tersebut mengajukan gugatan sendiri-sendiri atau secara individual ke pengadilan. Sehingga model gugatan. semacam itu sebenarnya dapat dijadikan alternatif bagi masyarakat dalam menyelesaikan perkara mereka melalui jalur litigasi secara lebih sederhana, cepat dan biaya ringan seperti yang diamanatkan dalam Pasal 4 ayat (1) UU No. 14 Tahun 1970 tentang Pokok-pokok Kekuasaan Kehakiman:2

Dalam perspektif historis, lembaga hukum legal standing dan class action sebenarnya mempunyai perbedaan asal usulnya. Lembaga hukum class action berasal dari sistem hukum common law, sedangkan lembaga hukum legal standing kalau dirunut berasal dari sistem hukum civil law.

Lembaga hukum class action sendiri sudah dikenal lama di negara-negara Anglo Saxon yang menganut sistem hukum common law. Pertama kali diperkenalkan di Inggris sekitar awal abad ke XVIII. Lembaga class ac-

'Sundari, "Pengajuan Gugatan secara Class Action (Suatu Studi Perbandingan dan Penerapannya di Indonesia)", dalam Thesis (Yogyakarta: UGM, 1999).

"Bambang Sutiyoso, "Implementasi Gugatan Class action dalam Praktik Peradilan di Indonesia", Jumal Hukum dan Keadilan, Vol. 2 No. 1 Oktober 1999. 
tion berkembang di negara-negara penganut common law lainnya, seperti di Kanada, Amerika Serikat, India, Australia dan negaranegara persemakmuran lainnya. ${ }^{3}$

Istilah class action berasal dari bahasa Inggris, yaitu gabungan kata class dan action. Pengertian class adaiah sekumpulan orang, benda, kualitas atau kegiatan yang mempunyai kesamaan sifat atau ciri, sedangkan pengertian action dalam dunia hukum adalah tuntutan yang diajukan ke pengadilan. Dengan demikian class action menggambarkan suatu pengertian di mana sekelompok besar orang berkepentingan dalam suatu perkara, satu atau lebih dapat menuntut atau dituntut mewakili kelompok besar orang tersebut , tanpa harus menyebutkan satu persatu anggota kelompok yang diwakili. ${ }^{4}$

Di beberapa negara, gugatan melalui class action sangat dimungkinkan dan mempunyai beberapa persyaratan yang harus dipenuhi, di antaranya: (1) numerousity atau jumlah yang mengajukan gugatan harus sedemikian banyaknya. Ini berarti class yang diwakili harus sedemikian banyaknya, sehingga apabila gugatan dilakukan secara individual, tidaklah praktis dan ekonomis; (2) commonality (kesamaan), yaitu harus ada kesamaan kepentingan antara pihak yang diwakili dan yang mewakili; (3) typically, yaitu tuntutan maupun pembelaan dari seluruh anggota yang diwakili harus sama dengan yang mewakili; (4) adequacy of representation (kelayakan perwakilan), yaitu perwakilan class hanya dapat diwakili dalam suatu gugatan (class action) apabila yang mewakili dapat dijamin secara jujur dan adil dapat melindungi kepentingan mereka yang mewakilkan. ${ }^{5}$

Indonesia tidak termasuk negara yang menganut sistem hukum common law, karena sistem hukumnya banyak dipengaruhi oleh hukum Belanda, yakni salah satu negara yang menganut sistem civil law. Di negara-negara yang menganut sistem civil lawsendir tidak mengenal lembaga class action, namun demikian dikenal bentuk lain dari prosedur pengajuan gugatan yang melibatkan kepentingan sejumlah besar orang secara perwakilan. Bangsa Romawi dalam kehidupan hukumnya mengenal adanya pengajuan gugatan yang melibatkan kepentingan umum secara perwakilan, yakni actio popularis. Menurut Kottenhagen-Edzes, ${ }^{6}$ dalam actio popularis setiap orang dapat menggugat atas nama kepentingan umum dengan menggunakan dasar ketentuan Pasal 1401. Niew BW (Pasal 1365 BW). Penyelenggaraan kepentingan umum merupakan tugas pemerintah, sehingga gugatan secara actio popularis pada umumnya ditujukan terhadap pemerintah.

Jika diperbandingkan, prinsip actio popularis mempunyai kesamaan dengan prinsip class action, yakni sama-sama

${ }^{3}$ Sundari, Pengajuan Gugatan Secara Class Action (Suatu studi Perbandingan dan Penerapannya di Indonesia (Yogyakarta: Universitas Atmajaya, 2002), hlm. v.

'Black, 1991, sebagaimana dikutip Sundari; op. cit., hlm. 8.

'Lihat tulisan Akhmad Santoso, "Gugatan Class Action di Indonesia", artikel dalam harian Kompas tanggal 5 Mei 1997.

${ }^{6}$ Paulus Efendi Lotulúng, 1993, sebagaimana dikutip oleh Sundari, op.cit., hlm. 16. 
pengajuan gugatan yang melibatkan kepentingan sejumlah besar orang secara perwakilan oleh seorang atau lebih. Perbedaannya adalah bahwa dalam actio popularis yang berhak mengajukan gugatan adalah setiap orang atas dasar bahwa ia adalah anggota masyarakat, tanpa ada keharusan bahwa orang tersebut merupakan pihak yang mengalami kerugian secara langsung. Dalam class action tidak setiap orang berhak mengajukannya, melainkan hanya salah satu atau beberapa orang yang merupakan anggota dari sekelompok orang yang ikut mengalami kerugian secara langsung. Kepentingan yang dituntut dalam actio popularis adalah kepentingan umum yang dianggap kepentingan setiap anggota masyarakat juga, sedang dalam class action kepentingan yang dituntut adalah kepentingan yang sama dalam suatu permasalahan yang menimpa kelompok tersebut.

Di negeri Belanda dikenal terminologi lain, yaitu groep acties yang mempunyai pengertian sebagai hak yang diberikan oleh suatu badan hukum untuk mengajukan gugatan mewakili kepentingan orang banyak (other person's interest), misalnya kepentingan perlindungan konsumen. Dalam prinsip group acties tersebut, badan hukum dapat:mengajukan gugatan mewakili kepentingan orang banyak apabila dalam Anggaran Dasarnya mencantumkan kepentingan yang serupa dengan yang diperjuangkan di pengadilan, yaitu memperjuangkan kepentingan orang banyak yang diwakilinya, namun tidak boleh menuntut ganti rugi. Prosedur groep acties telah memberi hak gugat kepada badan hukum untuk mewakili kepentingan orang banyak atau kepentingan umum. ${ }^{7}$

Apabila diperbandingkan, pengertian groep acties berteda dengan pengertian class action. Beberapa perbedaanya adalah groep acties merupakan perkembangan baru dalam hukum, terutama berkaitan dengan masalah tentang pemberian hak gugat (legal standing) bagi suatu badan hukum untuk mewakili kepentingan orang banyak. Badan hukum tersebut tidak pertu merupakan bagian dari kelompok yang diwakilinya atau tidak harus tinggal dalam satu daerah dengan masyarakat yang diwakili, namun cukup apabila di dalam Anggaran Dasarnya mencantumkan perlindungan kepentingan masyarakat banyak yang diwakilinya. Class action adalah permasalahan yang berkaitan dengan prosedur pengajuan perkara yang melibatkan sekelompok orang yang mempunyai kepentingan serta permasalahan yang sama. Perbedaan selanjutnya bahwa kepentingan yang dituntut dalam groep acties adalah kepentingan orang banyak dalam arti kepentingan umum dan tidak boleh menuntut ganti kerugian. Kepentingan yang dituntut dalam class action adalah kepentingan yang sama dari sekelompok orang yang bersifat individual, yang pada umumnya benupa tuntutan ganti kerugian. Badan hukum yang mengajukan tuntutan dalam groep acties tidak harus mengalami kerugian secara nyata, atau tidak hanus bertempat tinggal dalam satu daerah dengan masyarakat yang diwakili.

Pemberian hak gugat kepada badan hukum telah mengalami perkembangan pula, yang dengan memberikan hak gugat (legal standing) kepada organisasi non pemerintah (non govemment organization) dengan syarat

${ }^{7}$ lbid., hlm. 17. 
bahwa organisasi non pemerintah tersebut harus berbentuk badan hukum dan di dalam Anggaran Dasarnya mencantumkan kegiatan yang sama dengan yang diperjuangkan di pengadilan.

Dalam perkembangannya, Indonesia akhimya juga merespon adanya lembaga hukum tersebut dengan mengadopsi ke dalam beberapa peraturan perundang-undangan, yakni di dalam UU No. 23 Tahun 1997 tentang Pengelolalan Lingkungan Hidup, UU No. 8 Tahun 1999 tentang Perlindungan Konsumen, UU. No. 41 Tahun 1999 tentang Kehutanan, serta Perma No. 2 Tahun 1999 tentang Pengawasan MahkamahAgung Tertadap PantaiPoltk: ${ }^{8}$ Oleh karena itu dewasa ini dalam sistem hukum kita di samping dikenal gugatan class action, dikenal pula adanya prinsip legal standing (ius standi) dalam gugatan.

Legal standing dapat diartikan sebagai kualitas atau hak menggugat/berperkara ke pengadilan dengan mengatasnamakan kepentingàn kelompok masyarakat tertentu. ${ }^{9}$ Gugatan legal standing pada dasarnya dapat, diajukan baik oleh citizen standing (hak gugat warga) maupun oleh NGO (Non Govermental Organization) yang lebih dikenal dengan istilah ORNOP (Organisasi Non Pemerintah)..$^{10}$

Pada 2002, Mahkamah Agung mengeluarkan Perma No. 1 Tahun 2002, tentang Acara Gugatan Perwakilan Kelompok. Peraturan tersebut sudah lama ditunggutunggu, mengingat secara prosedural tata cara pengajuan gugatan perwakilan kelompok belum diatur dalam hukum formilnya. Menurut
Pasal 2 Perma No. 1 Tahun 2002, suatu gugatan dapat diajukan dengan mempergunakan tata cara gugatan perwakilan kelompok apabila:

a. Jumlah anggota kelompok sedemikian banyak sehingga tidaklah efektif dan efisien apabila gugatan dilakukan secara sendiri-sendiri atau secara bersamasama dalam satu gugatan;

b. Terdapat kesamaan fakta atau peristiwa dan kesamaan dasar hukum yang digunakan yang bersifat substansial, serta terdapat kesamaan jenis tuntutan di antara wakil kelompok dengan anggota kelompoknya;

c. Wakil kelompok memiliki kejujuran dan kesunggutian untuk melindungi kepentingan anggota kelompok yang diwakilinya;

d. Hakim dapat menganjurkan kepada wakil kelompok untuk melakukan penggantian pengacara, jika pengacara melakukan tindakan-tindakan yang bertentangan dengan kewajiban membela dan melindungi kepentingan anggota kelompoknya.

Selanjutnya Pasal 3 Perma No. 1 Tahun 2002 menyebutkan, selain harus memenuhi persyaratan-persyaratan formal surat gugatan sebagaimana diatur dalam Hukum Acara Perdata yang berlaku, surat gugatan perwakilan kelompok harus memuat:

a. Identitas lengkap dan jelas wakil kelompok;

b. Definisi kelompok secara rinci dan spesifik,

8/bid.

78.

${ }^{8}$ Bandingkan dengan Zairin Harahap, Hukum Acara PTUN (Jakarta: Rajagrafindo Persada, 2001), hlm.

${ }^{10}$ Majalah Forum Keadilan, 1997. 
walaupun tanpa menyebutkan nama anggota kelompok satu persatu;

c. Keterangan tentang anggota kelompok yang diperlukan dalam kaitan dengan kewajiban melakukan pemberitahuan;

d. Posita dari seluruh kelompok baik wakil kelompok maupun anggota kelompok, yang teridentifikasi maupun tidak teridentifikasi yang dikemukakan secara jelas dan rinci;

e. Dalam satu gugatan perwakilan dapat dikelompokkan beberapa bagian kelompok atau sub kelompok jika tuntutan tidak sama karena sifat dan kerugian yang berbeda;

f. Tuntutan atau petitum tentang ganti rugi harus dikemukakan secara jelas dan rinci, memuat usulan tentang mekanisme atau tata cara pendistribusian ganti kerugian kepada keseluruhan anggota kelompok termasuk usulan tentang pembentukan tim atau panel yang membantu memperlancar pendistribusian ganti kerugian.

Untuk mewakili kepentingan hukum anggota kelompok, menurut Pasal 4 Perma tersebut, wakil kelompok tidak dipersyaratkan memperoleh surat kuasa khusus dari anggota kelompok. Dengan demikian secara umum Perma 1 Tahun 2002 berupaya meminimalisir hambatan-hambatan prosedural yang diatur dalam hukum acara perdata yang secara substansial memang tidak mengatur tentang gugatan legal standing maupun class action.
Meskipun telah dikeluarkan Perma tersebut, tetapi substansinya masih sumir jika dimaksudkan untuk mengatur keseluruhan prosedur gugatan perwakilan kelompok, baik class action maupun legal standing, karena masih ada banyak aspek yang belum diatur di dalamnya." Sehingga dalam implementasinya dapat menimbulkan pemahaman dan interpretasi yang beragam. Tidak mengherankan kalau dalam menghadapi gugatan perwakilan kelompok selama ini masing-masing pengadilan menggunakan cara atau pedomannya sendirisendiri, sehingga tidak ada keseragaman dalam menanganinya. Ada hakim yang menyatakan menerima gugatan dan mengabulkannya, tetapi ada pula yang tidak menerimanya dan menolaknya karena hukum acaranya tidak ada. ${ }^{12}$ Meskipun demikian, sambil menunggu lahimya perundang-undangan baru yang akan mengatur nantinya, sementara Perma tersebut perlu dioptimalkan penggunaannya untuk memenuhi kebutuhan dalam praktik peradilan serta untuk mengisi kekosongan hukum (recht vacuum).

\section{Implementasi Gugatan Legal standing}

Berdasarkan ketentuan Pasal 38 UU No. 23 Tahun 1997 tentang Pengelolaan Lingkungan Hidup (PLH), organisasi lingkungan diberi hak gugat untuk mengajukan tuntutan atas nama kepentingan perlindungan lingkungan hidup. Hak tersebut terbatas pada tuntutan untuk melakukan atau tidak melakukan tindakan tertentu tanpa adanya tuntutan ganti kerugian, kecuali beaya

\section{${ }^{11}$ Sundari, loc. cit.}

${ }^{12}$ Sudikno Mertokusumo dalam pengantar buku karangan Sundari, Pengajuan Gugatan Secara Class action (Suatu studi Perbandingan dan Penerapannya di Indonesia (Yogyakarta: Universitas Atmajaya, 2002), hlm. ix. 
atau pengeluaran riil. Organisasi lingkungan hidup tersebut berhak mengajukan gugatan apabila memenuhi persyaratan, yaitu: (1) berbentuk badan hukum atau yayasan, (2) dalam Anggaran Dasamya menyebutkan dengan tegas bahwa tujuan didirikannya organisasi adalah untuk kepentingan pelestarian fungsi lingkungan hidup, dan (3) telah melakukan kegiatan sesuai Anggaran Dasamya.

Berdasarkan ketentuan Pasal 46 ayat (1) huruf c UU No. 8 Tahun 1999 tentang Perlindungan Konsumen, lembaga perlindungan konsumen swadaya masyarakat diberi hak untuk mengajukan tuntutan dengan mengatasnamakan kepentingan pertindungan konsumen. Syaratnya adalah: (1) harus berbentuk badan hukum atau yayasan, (2) daiam Anggaran Dasarnya menyebutkan dengan tegas bahwa tujuan didirikannya organisasi tersebut adalah untuk kepentingan perlindungan konsumen, dan (3) telah melaksanakan kegiatan sesuai dengan Anggaran Dasamya.

Ketentuan Pasal 73 UU No. 41 Tahun 1999 tentang Kehutanan, dalam rangka pelaksanaan tanggung jawab pengelolaan hutan, organisasi bidang kehutanan berhak mengajukan gugatan perwakilan untuk kepentingan pelestarian fungsi hutan. Organisasi bidang kehutanan tersebut berhak mengajukan gugatan apabila memenuhi syarat: (1) berbentuk badan hukum, (2) dalam Anggaran Dasarnya dengan tegas menyebutkan tujuan didirikannya organisasi untuk kepentingan pelestarian fungsi hutan, dan (3) telah melaksanakan kegiatan sesuai dengan Anggaran Dasamya.

Organisasi lingkungan, organisasi

${ }^{13}$ Sundari, op.cit, hlm. 32. perlindungan konsumen, organisasi bidang kehutanan adalah contoh Ornop-ornop di indonesia yang oleh peraturan perundangundangan telah diberi hak gugat (legal standing). Dengan demikian hak gugat Omop baru ada apabila telah diatur terlebih dahulu dalam suatu peraturan perundang-undangan.

Wakil kelompok dalam class action harus dibedakan dengan Ornop yang oleh peraturan diberi hak gugat (legal standing) mewakili kepentingan orang banyak misalnya para konsumen, kepentingan perlindungan lingkungan, dan hutan. Wakil kelompok dalam class action berasal dari kelompok yang mempunyai kepentingan dan mengalami kerugian yang sama dengan kelompk yang diwakilinya, sedangkan organisasi lingkungan, organisasi konsumen, organisasi kehutanan dan sebagainya, bukan pihak yang mengalami kerugian atau permasalahan secara konkrit. Organisasi konsumen hanya merupakan pihak yang mempunyai kepentingan untuk melindungi konsumen secara keseluruhan dari perbuatan melawan hukum (PMH) yang dilakukan oleh pelaku usaha. Organisasi lingkungan hanyalah pihak yang mempunyai kepentingan untuk melestarikan dan melindungi lingkungan dari kerusakan atau pencemaran. Kerugian sebagai akibat rusaknya atau tercemarnya lingkungan yang dituntut oleh organisasi lingkungan didasarkan pada pengertian bahwa lingkungan merupakan milik bersama, yang menuntut pula tanggung jawab bersama untuk melestarikan dan melindunginya. ${ }^{13}$

Meskipun beberapa peraturan perundangundangan di atas sudah meletakkan dasardasar gugatan perwakilan kelompok, akan tetapi implementasinya sering dihadapkan 
pada kendala teknis prosedural. Karena dalam hukum acara perdata positif Indonesia dianggap tidak mengatur prosedur gugatan perwakilan kelompok sebagaimana dimaksud dalam UU Pengelolaan Lingkungan Hidup, UU Perlindungan Konsumen maupun dalam UU Kehutanan.

Di Indonesia, ada beberapa kasus gugatan perwakilan kelompok, baik gugatan legal standing maupun class action yang pernah diajukan ke pengadilan baik yang dipublikasikan maupun tidak terpublikasi, di antaranya:

1. Gugatan R.O. Tambunan yang mengatasnamakan orang tua, remaja dan generasi muda di seluruh Indonesia yang menghisap rokok Bentoel terhadap PT. Rokok Bentoel di PN Jakarta Pusat pada tahun 1987. Gugatan tersebut dinyatakan tidak diterima.

2. Gugatan Mochtar Pakpahan yang mengatasnamakan warga DKI Jakarta yang menderita sakit demam berdarah kepada Gubernur DKI Jakarta dan kepala Dinas Kesehatan DKI Jakarta di Pengadilan Negeri Jakarta Pusat pada tahun 1988.

3. Gugatan Chairul Dana, dkk. Yang mewakili seluruh buruh PT. Industri Sandang I melawan PT. Industri Sandang I dan Departemen Tenaga Kerja RI di PN Jakarta Selatan pada tahun 1992.

4. Gugatan 17 warga yang mengatasnamakan seluruh warga yang berdomisili di sekitar sungai Ciujung yang mengalami pencemaran kepada PT. Indah Kiat Pulp and Paper dan Pemda Tingkat I Jawa Barat di PN Jakarta Utara.

5. Gugatan WALHI kepada PT. Inti Indorayon Utama dalam kasus pencemaran lingkungan-di PN Jakarta Pusat tahun 1989.

6. Gugatan WALHI melawan Presiden RI terhadap pemanfaatan dana reboisasi

7. Gugatan korban melawan developer dalam kasus perumahan fiktif di Tangerang

8. Gugatan warga dalam kasus Kali Tapak Semarang.

9. Gugatan YLKI terhadap Perusahaan Listrik Negara (PLN) mewakili masyarakat konsumen yang merasa dirugikan berkaitan dengan terjadinya pemadaman aliran listrik pada tanggal 13 April $1997 \mathrm{di}$ PN Jakarta Selatan.

10. Gugatan PBHI, ELSAM dll. Yang mewakili masyarakat Jakarta dan Solo kepada Pemerintah RI dalam kasus "12-15 Mei berdarah" di PN Jakarta Pusat pada tahun 1998.

11. Gugatan Serikat Pengacara Rakyat (SPR) kepada Presiden RI atas kenaikan harga BBM, Listrik dan Telepon di PN Jakarta Pusat tahun 2003.

12. Gugatan AJI terhadap Kapolri dalam perkara Perbuatan Melawan Hukum (PMH) di PN Jakarta Pusat tahun 2003.14 Dari beberapa kasus di atas, pada umumnya gugatan dinyatakan tidak diterima atau N.O. oleh pengadilan, kecuali gugatan

${ }^{14} \mathrm{Di}$ antara kasus yang menarik perhatian publik akhir-akhir ini, khususnya pemerhati hukum adalah gugatan legal standing yang diajukan oleh Aliansi Jurnalis Independen (AJl) Jakarta kepada pejabat kepolisian, yaitu Kapolri c.q. Kapolda Metro Jaya c.q. Kapolres Jakarta Pusat c.q. Kepala Polsek Menteng dalam perkara Perbuatan Melawan Hukum (PMH) di Pengadilan Negeri Jakarta Pusat. Kasus ini cukup menarik, mengingat 
WALHI kepada PT Inti Indorayon Utama(1989) dan Gugatan AJI kepada Kapolri yang dinyatakan diterima dan dikabulkan sebagian gugatannya (2003).

Walaupun sampai saat ini beberapa kasus gugatan legal standing maupun class action diajukan ke pengadilan, namun gugatan semacam itu masih menimbulkan dilema dalam praktik. Di satu sisi gugatan legal standing dan class action mencerminkan pelaksanaan asas peradilan yang sederhana, cepat dan biaya ringan akan tetapi di sisi lain masih dihadapkan dengan prosedur aturan mainnya (rule of game), terutama tata cara pengajuan gugatan legal standing dan class action belum diatur secara jelas dalam hukum formal (hukum acara perdata) yang berlaku. Dengan kata lain ketentuan perundang-undangan yang mengatur tentang gugatan perwakilan kelompok ternyata masih sebatas dalam ruang lingkup kriteria hukum materiilnya, tetapi tidak diatur lebih lanjut ketentuan hukum acaranya. Tidak mengherankan dalam praktik, institusi peradilan masih terkesan sangat hati-hati untuk dapat menerima dan mengabulkan model gugatan semacam ini.

\section{Syarat Gugatan dalam Hukum Acara Perdata}

Hukum acara perdata adalah hukum yang bertungsi untuk menegakkan, mempertahankan dan menjamin ditaatinya hukum perdata material dalam praktik melalui perantaraan hakim. Oleh karena itu bagi orang yang merasa hak perdatanya dilanggar, ia dapat mengajukan perkaranya ke pengadilan, yaitu dengan mengajukan tuntutan hak (gugatan) terhadap pihak-pihak yang dianggap merugikan, agar memperoleh penyelesaian sebagaimana mestinya. Karena pada prinsipnya setiap orang yang merasa mempunyai hak dan ingin

Majelis Hakim Pengadilan Negeri Jakarta Pusat yang diketuai Iskandar, SH dengan anggota majelis masingmasing Andi Samsan Nganro, SH dan Ny. Andriani Nurdin, SH dalam putusannya pada tanggal 6 Oktober 2003 telah mengabulkan sebagian gugatan penggugat dengan menyatakan para pejabat kepolisian di atas terbukti melakukan PMH. Padahal dalam praktik peradilan selama ini jarang sekali gugatan legal standing yang diajukan ORNOP (Organisasi non pemerintah) semacam AJl yang diterima dan dikabulkan pengadilan.

Seperti diketahui, kasus tersebut bermula dari diajukannya gugatan legal standing oleh AJI Jakarta melalui Komite Pembela Kebebasan Pers (KPKP), karena aparat Polisi dianggap membiarkan tindak kekerasan oleh massa Group Artha Graha di kantor Tempo dan kantor Polres Jakarta Pusat pada tanggal 8 Maret 2003. Pada saat itu massa pendukung Group Artha Graha memprotes berita majalah Tempo berjudul "Ada Tomy di Tenabang" yang dianggap mencemarkan nama baik Tommy Winata selaku bos Group Artha Graha. Dalam hal ini Polisi dianggap tidak melakukan tugas dan kewajibannya secara profesional sebagaimana diatur dalam perundang-undangan, yaitu Polisi tidak bersikap tegas dan memadai dalam upaya melakukan pengamanan dan perlindungan terhadap para Jurnalis Tempo. Polisi tidak melakukan langkah-langkah pencegahan dan membiarkan terjadinya tindak kekerasan atas jurnalis Tempo, masing-masing Ahmad Taufik, Abdul Manan, Bambang Harymurt dan Karaniya Dharmasaputra. Sikap Polisi seperti itu dapat dikategorikan melakukan PMH, oleh karenanya majelis hakim kemudian menghukum para tergugat agar meminta maaf secara terbuka kepada para jurnalis bersangkutan dan AJI Jakarta baik melalui media cetak maupun elektronik. Disarikan dari harian Kompas, tanggal 7 Oktober 2003, hlm. 7 . 
menuntut atau mempertahankannya, dapat memperkarakannya di muka pengadilan (legitima personae standi in judicio).

Meskipun demikian para pihak yang hendak berperkara di pengadilan disyaratkan mempunyai kecakapan atau kemampuan untuk bertindak hukum (handelings bekwaamheid). Orang yang tidak cakap melakukan perbuatan hukum secara otomatis juga tidak dapat berlaku sebagai pihak-pihak di muka pengadilan. Di samping itu pihakpihak yang bersangkutan juga harus mempunyai kewenangan menjadi pendukung hak (rechtsbevoegheid), artinya meskipun orang tersebut cakap berbuat hukum tapi tidak mempunyai kewenangan menjadi pendukung hak dalam suatu perkara, maka ia tidak dapat memperkarakannya di pengadilan.

Di samping itu suatu gugatan juga harus mempunyai kepentingan hukum yang cukup, sebagai syarat utama untuk dapat diterimanya tuntutan hak itu oleh pengadilan..$^{15}$ Sehingga ada ungkapan point d'interet point d'action, artinya kalau tidak ada kepentingan maka tidak akan ada proses. Demikian pula dalam Pasal 8 Rv ditegaskan bahwa suatu gugatan harus jelas dan lengkap. ${ }^{16}$ Apabila suatu gugatan diwakilkan kepada orang lain, maka harus ada pemberian kuasa yang sah dengan surat kuasa khusus dari pihak yang mewakilkan (pemberi kuasa) kepada pihak yang mewakili (pemegang kuasa).

Dalam Hukum Acara Perdata, suatu gugatan pada . prinsipnya juga harus memenuhi syarat material maupun syarat formal. Syarat material adalah syarat yang berkaitan dengan isi atau materi yang harus dimuat dalam surat gugatan. Dalam hal syarat materiil, pada umumnya para advokat atau pengacara praktik cenderung mengikutj aturan main yang ditentukan dalam Pasal 8 ayat $3 \mathrm{Rv}$, yang menggariskan bahwa suatu gugatan harus memuat identitas para pihak, dasardasar daripada gugatan (posita atau fundamentum petendi) serta adanya petitum (tuntutan).

Sedang syarat formal gugatan, adalah syarat untuk memenuhi ketentuan tata tertib beracara yang ditentukan oleh peraturan perundang-undangan. Jika ternyata ada salah satu syarat formal yang tidak dipenuhi, mengakibatkan gugatan tidak sah, sehingga gugatan tersebut harus dinyatakan tidak dapat diterima (niet onvankelijke verklard). Syaratsyarat formal yang harus dipenuhi di antaranya adalah: ${ }^{17}$

1. Tidak melanggar kompetensi atau kewenangan mengadili baik kompetensi absolut maupun kompetensi relatif.

2. Gugatan tidak mengandung error in persona (kekeliruan pada orang atau pihakpihaknya). Contohnya: (1) penggugat belum dewasa, dibawah pengampuan, atau tidak punya hak dan kepentingan. (2) kuasa yang mewakili tidak memenuhi syarat, seperti tidak mendapatkan kuasa

${ }^{15}$ Sudikno Mertokusumo, Hukum Acara Perdata Indonesia (Yogyakarta: Liberty, 1993), him. 39.

${ }^{18}$ Gugatan yang kabur dan kurang sempurna yang berisi dalil-dalil yang saling bertentangan satu sama lain (obscuur libellel) atau gugatan yang tidak lengkap pihak-pihaknya (plurium litis consortium), akan berakibat gugatan tersebut dinyatakan tidak diterima (niet onvankelijke verklaard).

${ }^{17}$ M. Yahya Harahap, Hukum Acara Perdata (Medan: Program Pasca Sarjana IImu Hukum Universitas Sumatera Utara, 1995), hlm. 19-36. 
baik lisan/tertulis, atau surat kuasa khusus tidak sah. (3) Orang yang ditarik sebagai tergugat tidak tepat atau tidak lengkap (plurium litis consortium), seperti pengurus yayasan digugat secara pribadi; harta sengketa tidak lagi dikuasai tergugat tapi sudah beralih ke pihak ketiga, maka pihak ketiga juga harus ikut digugat.

3. Gugatan harus jelas dan tegas (Pasal 8 Rv). Gugatan yang tidak jelas atau tidak sempurna yang berisi pernyataan yang bertentangan satu sama lain (Obscuur Libellel ) dapat berakibat gugatan dinyatakan tidak diterima. Contoh gugatan yang tidak jelas: (1) posita tidak menjelaskan peristiwa atau kejadian serta dasar hukum yang mendasari gugat, (2) tidak jelas obyek yang disengketakan, seperti tidak menyebut lokasi, tidak jelas batas, ukuran dan luasnya, tidak ditemukan obyek sengketa, (3) posita bertentangan dengan petitum, (4) petitum tidak terinci, tapi hanya berupa kompositur (ex aequo et bono atau mohon putusan yang seadil-adilnya).

4. Tidak melanggar asas nebis in idem (mengajukan gugatan untuk kedua kalinya atas perkara yang obyek maupun subyeknya sama).

5. Gugatan tidak prematur atau belum waktunya menggugat sudah menggugat. Contohnya gugatan warisan baru terbuka apabila pewaris sudah meninggal dunia. Selama pewaris masih hidup, maka gugatan warisan menjadi tertunda. Demikian juga gugatan utang piutang dapat dilakukan harus menunggu sampai jatuh tempo waktunya tiba.

6. Tidak menggugat hal-hal yang telah dikesampingkan. Sebagai contoh: (1) apa yang digugat sudah dipenuhi atau dihapuskan sendiri oleh penggugat, (2) penggugat sudah melepaskan haknya, seperti menolak sebagai ahli waris, (3) gugatan sudah lewat wakti (daluarsa). Pasal 1967 BW menyebutkan bahwa tuntutan hak baik bersifat kebendaan dan perorangan menjadi hapus (daluarsa) setelah lampau waktu 30 tahun.

7. Apa yang digugat sekarang masih tergantung pemeriksaannya dalam proses peradilan (aanhanging geding $/ \mathrm{rei}$.judicata deductae). Hal ini dapat terjadi karena perkara yang digugat sudah pernah diajukan dan belum putus serta prosesnya masih berlangsung pada tingkat banding atau kasasi.

Dalam hukum acara perdata positif sebenarnya juga dikenal adanya gugatan secara perwakilan. Makna gugatan secara perwakilan di sini meliputi : (1) gugatan secara perwakilan karena penunjukan oleh hukum, dan (2) gugatan secara perwakilan karena penunjukan oleh pihak yang berkepentingan. ${ }^{1 B}$

Pada gugatan secara perwakilan yang pertama, orang yang maju ke pengadilan tidak perlu mendapatkan surat kuasa dari orang atau badan hukum yang diwakilinya. Yang menjadi dasar adalah karena hukum telah memberikan wewenang kepada orang tersebut untuk maju ke pengadilan mewakili kepentingan orang-orang yang tidak mempunyai kemampuan untuk bertindak (personae miserabiles) atau badan hukum. Karena

${ }^{18}$ Sundari, op. cit., hlm. 140. 
telah diberi wewenang oleh hukum, maka orang yang maju ke pengadilan dalam hal tersebut mempunyai kewenangan untuk bertindak sebagai pihak di pengadilan (legitima personae standi in judicio). Termasuk dalam kategori ini, orang tua dan wali diberi legitima personae standi in judicio untuk mewakili kepentingan anaknya atau anak di bawah perwaliannya. ${ }^{19}$ Pengurus badan hukum atau badan usaha dagang diberi legitima personae standi in judicio untuk mewakili kepentingan badan hukum atau badan usaha dagang tesebut. ${ }^{20}$ Pimpinan departemen, jaksa, pejabat yang ditunjuk dan kepala daerah diberi untuk mewakili kepentingan negara dalam berperkara perdata. ${ }^{21}$

Pada gugatan secara penwakilan yang kedua, orang yang maju ke pengadilan untuk mewakili kepentingan orang lain harus mendapat kuasa dari orang yang diwakilinya, karena hukum tidak menunjuknya. Orang yang nemberi kuasa sebenarnya mempunyai kemampuan untuk bertindak menuntut kepentingannya secara pribadi di pengadilan. Berhubung suatu alasan di luar yang diatur oleh hukum, orang tersebut tidak dapat maju sendiri ke pengadilan. Termasuk dalam kategori ini adalah para pengacara atau advokat yang mewakili kepentingan seseorang atau badan hukum dalam beracara di pengadilan.

Kalau diperhatikan syarat-syarat gugatan dan cara perwakilan yang ada dalam Hukum Acara Perdata, maka gugatan legal standing dan class action mempunyai kemiripan dengan gugatan secara perwakilan yang pertama, yaitu gugatan secara perwakilan karena adanya penunjukan oleh hukum. Dalam hal ini karena hukum telah memberikan wewenang kepada orang tersebut untuk maju ke pengadilan, maka orang yang maju ke pengadilan tidak perlu mendapatkan surat kuasa dari orang atau badan hukum yang diwakilinya.

Meskipun sebenarnya ada kesamaan prinsip antara gugatan perwakilan kelompok dengan gugatan secara perwakilan dalam perkara perdata, namun di dalam praktik masih sering ada anggapan bahwa gugatan legal standing dan class action tidak sesuai atau tidak memenuhi beberapa persyaratan prosedural hukum acara perdata. Syarat-syarat yang dianggap belum terpenuhi antara lain:

1. Syarat adanya hak dan kepentingan hukum yang cukup dalam suatu gugatan.

Dalam gugatan class action, pihak yang mengajukan gugatan masih dipertanyakan kewenangannya dalam mewakili kepentingan kelompok masyarakat yang dirugikan. Pihak yang mewakili tidak mendapatkan kuasa dari kelompok masyarakat. Karena itulah mereka dianggap tidak mempunyai kepentingan hukum yang cukup dalam mengajukan gugatan yang mengatasnamakan kepentingan kelompok masyarakat tersebut.

2. Syarat gugatan harus jelas dan lengkap.

Dalam gugatan class action, karena jumlah kelompok masyarakat yang berkepentingan

${ }^{19}$ Lihat Pasal 383, 403-405, 452 KUH

20 Lihat Pasal 6 No. 3 Rv, 1655 KUH Perdata.

${ }^{29}$ Lihat Pasal 6 No. 2 Rv, Pasal 27 ayat (2) UU No. 5 Tahun 1991, Pasal 23 ayat (1) UU No. 5 Tahun 1974. 
cukup banyak, sehingga tidak mungkin dituliskan semua identitasnya dalam surat gugatan, tetapi hanya identitas pihak yang mewakili saja. Ini berarti gugatan tersebut gugatan yang tidak jelas dan tidak lengkap pihak-pihaknya (plunium litis cosortium). Hal ini akan berakibat gugatan dinyatakan tidak diterima

3. Syarat apabila gugatan diwakilkan harus ada pemberian kuasa yang sah kepada pemegang kuasa. Dalam gugatan legal standing maupun class action tidak ada pemberian kuasa yang sah dari masyarakat yang berkepentingan kepada pihak yang mewakili mengajukan gugatan. Dengan demikian gugatan yang semacam itu dianggap tidak sah.

\section{Terobosan Hukum}

Seperti diuraikan di atas, bahwa Hukum Acara Perdata tidak mengatur secara jelas prosedur gugatan secara legal standing maupun class action. Akan tetapi, dengan tidak diaturnya prosedur acara gugatan dalam Hukum Acara Perdata, sebenarnya bukanlah merupakan "harga mati" bahwa upaya gugatan legal standing dan class action sama sekali tidak dibenarkan dan tidak dapat diterima dalam praktik peradilan kita.

Sebenarnya yang diperlukafrdi sini adalah adanya keberanian hakim untuk melakukan terobosan hukum dengan melakukan penemuan hukum (rechsvinding), dalam upaya membuat putusan-putusan yang memenuhi perasaan keadilan masyarakat meskipun suatu perkara tidak diatur secara jelas dalam perundang-undangan. Hakim dapat menggunakan metode penemuan hukum yang ada, seperti interpretasi, analogi maupun eksposisi/konstruksi hukum. Terlebih dalam hal ini sudah ada Perma No. 1 Tahun 2002 sebagai dasar acuannya. Hakim tidak perlu terpaku pada undang-undang saja, tetapi hakim dapat mempergunakan sumber hukum lainnya seperti hukum kebiasaan, yurisprudensi, doktrin, Sema/Perma.

Seorang hakim harus memecahkan atau menyelesaikan peristiwa konkrit dan untuk itu ia harus tahu, mencari atau menemukan hukumnya untuk diterapkan pada kasusnya. ${ }^{22}$ Seorang hakim sebagai penegak hukum dan keadilan wajib menggali, mengikuti dan memahami nilai-nilai yang hidup dalam masyarakat. ${ }^{23}$ Sehingga tidak perlu terlebih dahulu menunggu lahirnya Kitab UndangUndang, Húkum Acara Perdata yang baru (yang mungkin nanti akan mengatur masalah gugatan perwakilan kelompok). Dengan adanya yurisprudensipun dapat dijadikan sumber hukum bagi hakim yang lain dalam menjatuhkan putusannya.

Dengan diakui dan diterimanya gugatan perwakilan, baik legal standing dan class action tersebut dalam praktik, maka terdapat beberapa manfaat utama, yaitu : (1) mencapai peradilan yang lebih ekonomis, (2) memberi peluang yang lebih besar ke pengadilan, dan (3) merubah perilaku yang tidak pantas dari para pelanggar atau orang-orang yang potensial melakukan pelanggaran. ${ }^{24}$

\footnotetext{
22 Sudikno Mertokusumo, Penemuan Hukum Sebuah Pengantar(Yogyakarta: Liberty, 1996), hlm. 39.

${ }^{23}$ Lihat pasal 27 ayat 1 UU No. 14 Tahun 1970 tentang Ketentuan Pokok Kekuasaan Kehakiman.

${ }^{24}$ Ontario Law Reform Commission, 1982 sebagaimana dikutip Sundari, op.cit., hlm. 27.
} 
Prosedur gugatan perwakilan akan memberikan manfaat bagi kedua belah pihak serta bagi sistem peradilan, karena prosedur tersebut mengurangi keseluruhan biaya perkara yang harus dikeluarkan serta jumlah gugatan yang harus diajukan dalam hal terjadi sengketa yang melibatkan orang banyak. Tidaklah praktis bagi pengadilan dan juga bagi para pihak apabila harus melayani gugatan-gugatan sejenis yang diajukan secara individual atau secara joinder. Dengan diajukannya perwakilan oleh seorang atau lebih yang merupakan wakil dari seluruh anggota kelompok, maka kepentingan seluruh? kelompok sekaligus dapat dituntut. Peluang bagi para pihak ke pengadilan akan lebih besar, lebih-lebih jika secara individual para pihak mengalami hambatan-hambatan untuk maju ke pengadilan, misalnya hambatan keuangan, sosial dan psikologis. Dengan diajukannya gugatan oleh seorang atau beberapa orang saja; maka kepentingan anggota kelompok lainnya yang kebetulan ঢidak mampu dari segi keuangan, sosial dan psikologis sudah terwakili kepentingannya tanpa mereka harus maju sendiri ke pengadilan. ${ }^{25}$

Memarig kalau dicermiati Pasal 393 HIR ayat (1), yang menyebutkan adanya larangan menggunakan aturan lain selain yang diatur dalam HIR, yaitu dalam mengadili perkara dihadapan pengadilan negeri maka tidak boleh diperhatikan peraturan lain atau yang melebihi daripada yang ditentukan dalam reglement ini. Terhadap ketentuan Pasal 393
HIR tersebut, Subekti memberikan komentar sebagai berikut:

"Dengan tidak menghiraukan larangan dalam Pasal 393 HIR untuk memakai bentuk-bentuk acara lain, selain yang telah diberikan HIR itu sendiri, Yurisprudensi dan praktik peradilan sudah mengintrodusir berbagai bentuk acara yang tidak dikenal oleh HIR misalnya penggabungan atau penyertaan (voeging), intervensi, request civil dan lain-lain ..., sehingga Pasal 393 HIR itu memang sungguh-sungguh sudah uitgehold (digerogoti hingga menjadi kosong), seperti dikatakan oleh para sarjana hukum sebelum perang dunia $\|^{n} .^{26}$

Di dalam praktik para hakim seyogyanya berlaku luwes dan tidak terlalu kaku dalam mensikapi ketentuan Pasal 393 HIR tersebut, karena penggunaan lembaga-lembaga lain yang tidak diatur dalam HIR tetap saja berlangsung, seperti acara intervensi, dan voeging. Pengadilan Negeri Jakarta pemah menerobos Pasal 393 HIR dalam masalah "kortgeding" atau pemeriksaan kilat, dengan didasarkan alasan jika perlu Pengadilan Negeri dapat menggunakan lembaga yang terdapat dalam Rv asal dalam ciptaannya sendini, artinya tidak mendasarkan pada peraturan yang terdapat dalam Rv tersebut. ${ }^{2 i}$

Dalam hal ini Sudikno Mertokusumo, berpendapat bahwa dapat saja hakim menggunakan lembaga-lembaga hukum acara perdata yang disebut dalam instruksi atau surat edaran Mahkamah Agung asal saja sebágai ciptaan sendiri tanpa menunjuk kepada instruksi atau sụrat edaran yang

\footnotetext{
${ }^{25} \mathrm{lbid}$ :

${ }^{26}$ Chaidir Ali, Responsi Hukum Acara Perdata (Bandung: Armico, 1987), hlm. 16.

${ }^{27}$ Ibid., hlm. 17.
} 
bersangkutan. ${ }^{28}$ Jadi hal ini terserah kepada kebijaksanaan hakim sendiri.

Di samping itu secara yuridis, tiap orang yang dirugikan dapat menuntut ganti rugi terhadap pihak yang menyebabkan terjadinya kerugian. Hal ini berdasarkan prinsip hukum yang sterkandung dalam Pasal $1365 \mathrm{KUH}$ Perdata, bahwa "tiap perbuatan melanggar hukum, yang membawa kerugian kepada seorang lain, mewajibkan orang yang karena salahnya menerbitkan kerugian itu, mengganti kerugian tersebut." Ketentuan dalam pasal ini tidak menyebut berapa jumlah orangnya, asalkan melanggar hukum dan merugikan orang lain, maka dapat dituntut untuk mengganti kerugian. Dalam konteks hukum, siapapun yang melanggar hukum, maka ia harus bertanggung jawab atas perbuatannya.

Berdasarkan kerangka berpikir di atas, tidak perlu lagi-lembaga peradilan bersikap kaku dengan tidak mengakui dan tidak menerima keberadaan lembaga hukum legal standing maupun class action dengan alasan prosedumya tidak diatur dalam undang-undang. Dari pengalaman kasus-kasus di atas tampaknya tidak dapat dipertahankan terus. Perkembangan masyarakat yang ada sekarang membutuhkan pula perkembangan hukum, termasuk masalah prosedur yang dapat menunjang tegaknya keadilan dan kebenaran. Selain itu tujuan pokok yang hendak dicapai dari prosedur hukum adalah menciptakan peradilan yang sederhana, cepat dan biaya ringan, sebagaimana diamanatkan dalam Undang-Undang No. 14 tahun 1970, tentang Ketentuan-ketentuan Pokok Kekuasaan Kehakiman.
Amanat yang dituangkan dalam undangundang tersebut hanya dapat diwujudkan melalui proses administrasi yang tidak berbelit-belit, efisien dan tidak mengeluarkan banyak biaya. Dalam proses peradilan mengajukan gugatan berarti pula mengeluarkan sejumlah biaya tertentu yang telah ditetapkan. Dalam kaitannya dengan proses peradilan yang sederhana, cepat dan biaya ringan, maka gugatan legal standing dan class action menjadi sangat relevan untuk diterapkan.

Oleh karena itulah sudah waktunya para hakim harus berani melakukan terobosan hukum untuk mengakui dan menerima secara prosedural keberadaan gugatan legal standing maupun class action dari masyarakat, seperti di negara-negara maju lainnya. Dan kepada pihak petinggi negara yang berwenang perlu kiranya untuk segera merespons perkembangan masyarakat dan perkembangan hukum, dengan membuat perangkat aturan perundang-undangan yang mengatur tentang prosedur acara gugatan legal stahding dan class action ini, khususnya dalam hukum acara perdata yang baru nantinya.

\section{Simpulan}

Implementasi gugatan perwakilan kelompok, khususnya legal standing dalam praktik peradilan di Indonesia sampai sekarang ini masih sering dihadapkan pada kendala yang bersifat teknis prosedural. Peraturan perundangundangan yang mengaturnya masih sebatas hukum materiil, sedangkan dalam hukum formilnya (hukum acara perdata) tidak diatur

${ }^{28}$ Sudikno Mertokusumo, op. cit., hlm. 10. 
secara jelas. Ketiadaan ketentuan prosedural dalam hukum formil (hukum acara perdata) yang mengaturnya, sebenamya bukan merupakan halangan bagi hakim untuk memberikan putusan yang adil, karena hakim dapat mempergunakan sumber hukum lainnya. Hakim harus mempunyai keberanian untuk melakukan terobosan hukum dengan menggunakan penemuan hukum (rechtsvinding) sehingga eksistensi gugatan legal standing dapat diakui dan diterima dalam praktik peradilan di Indonesia.

Meskipun telah dikeluarkan Perma No. 1 Tahun 2002 yang mengatur acara gugatan perwakilan kelompok, kedepan eksistensinya perlu dirumuskan dengan tegas dalam ketentuan Kitab Undang-Undang Hukum Acara Perdata yang baru. Gugatan perwakilan . kelompok semacam ini merupakan altematif peradilan yang lebih sederhana, cepat dan biaya ringan, oleh karena itu amat dibutuhkan dalam praktik sesuai dengan tuntutan zaman.

Putusan PN Jakarta Pusat yang menerima dan mengabulkan sebagaian gugatan AJI terhadap Kapolri c.s. beberapa waktu yang lalu, merupakan momentum yang baik bagi dunia hukum dan peradilan. Putusan yang langka tersebut perlu di dukung karena dapat menjadi media pendidikan publik dan secara tidak langsung tentunya telah mengakui dan memantapkan eksistensi gugatan legal standing di Indonesia.

\section{Daftar Puștaka}

Ali, Chaidir, Responsi Hukum Acara Perdata, Bandung: Armico, 1987.

Harahap, M. Yahya, Hukum Acara Perdata, Medan: Program Pasca Sarjana Ilmu Hukum Universitas Sumatera Utara, 1995.

Mertokusumo, Sudikno dalam pengantar buku karangan Sundari, Pengajuan Gugatan Secara Class action (Suatu studi Perbandingan dan Penerapannya di Indonesia), Yogyakarta: Universitas Atmajaya, 2002.

- Hukum Acara Perdata Indonesia, Yogyakarta: Liberty, 1993.

-__, Penemuan Hukum Sebuah Pengantar, Yogyakarta: Liberty, 1996.

Sundari, Pengajuan Gugatan Secara Class Action (Suatu studi Perbandingan dan Penerapannya di Indonesia), Yogyakarta: Universitas Atmajaya, 2002.

Sutiyoso, Bambang, "Implementasi Gugatan Class action Dalam Praktik Peradilan di Indonesia," dalam Jumal Hukum dan Keadilan, Vol. 2 No. 1 Oktober 1999.

UU No. 5 Tahun 1974.

KUH Perdata

Harian Kompas tanggal 5 Mei 1997.

Harian Kompas, tanggal 7 Oktober 2003

Majalah Forum Keadilan, 1997. 